\title{
Effects of both Pro- and Synbiotics in Liver Surgery and Transplantation with Special Focus on the Gut-Liver Axis-A Systematic Review and Meta-Analysis
}

\author{
Judith Kahn ${ }^{1}$, Gudrun Pregartner ${ }^{2}$ and Peter Schemmer ${ }^{1, *}$ \\ 1 General, Visceral, and Transplant Surgery, Department of Surgery, Medical University of Graz, \\ 8036 Graz, Austria; judith.kahn@medunigraz.at \\ 2 Institute for Medical Informatics, Statistics and Documentation, Medical University of Graz, \\ 8036 Graz, Austria; gudrun.pregartner@medunigraz.at \\ * Correspondence: peter.schemmer@medunigraz.at; Tel.: +43-316-385-84094
}

Received: 10 July 2020; Accepted: 13 August 2020; Published: 15 August 2020

\begin{abstract}
The gut-liver axis is of upmost importance for the development of infections after surgery. Further bacterial translocation due to surgery-related dysbiosis is associated with limited detoxification function of the liver compromising outcome of surgical therapy. After liver surgery, about $30 \%$ of patients develop a bacterial infection, with the risk of bacteremia or even sepsis-associated liver failure and mortality in $>40 \%$. The potential benefit of pro-/synbiotics given before surgery is still under debate. Thus, a systematic literature search on trials comparing patients with or without supplementation and outcome after liver resection or transplantation was performed. Our search strategy revealed 12 relevant studies on perioperative administration of pro-/synbiotics in liver surgery. The pro-/synbiotic combinations and concentrations as well as administration timeframes differed between studies. Five studies were performed in liver transplantation and 7 in liver resection. All studies but one reported lower infection rates (pooled RR: 0.46, 95\% CI: 0.31-0.67) with pro-/synbiotics. Liver function was assessed after LT/LR in 3 and 5 studies, respectively. Pro-/synbiotics improved function in $1 / 3$ and $2 / 5$ studies, respectively. Concluding, perioperative pro-/synbiotics clearly reduce infection after liver surgery. However, standard protocols with both well-defined probiotic strain preparations and administration timeframes are pending.
\end{abstract}

Keywords: pro-/synbiotic; liver surgery; liver transplantation; gut-liver axis

\section{Introduction}

Liver cirrhosis and hepatic tumors are often the final stage of a chronic liver disease. Surgical therapy, either liver resection (LR) or liver transplantation (LT) can be regarded as therapy of choice in most cases.

LR, which is especially performed for tumors, is associated with both mortality and morbidity of $3.5 \%$ and $10-15 \%$, respectively [1-15]. About $30 \%$ of patients develop a bacterial infection and about $10 \%$ intra-abdominal sepsis, mostly caused by enterogenic bacteria after LR. The incidence of bacterial infections increases to up to $45 \%$ after extensive LR. With bacteremia, the risk of liver failure increases to $>50 \%$ with a mortality of $>40 \%[1,14,15]$. Postoperative infections are the main reason for both morbidity and mortality, which are also associated with high treatment costs [16]. General risk factors include malnutrition and parenteral nutrition. The surgical trauma per se, direct manipulation of the intestine during abdominal surgery, reduced postoperative intestinal motility, and a limited detoxification function of a diseased liver decrease outcome quality of surgery. Even perioperative 
antibiotics as well as analgesics and proton pump inhibitors support a dysbiosis in the gut, which further increases the risk of infection.

Preoperative malnutrition especially increases infectious complications after LT [17], and decreased liver function before LT may be related to postoperative bacteremia [18]. Immunosuppression after LT per se further potentiates this risk for infections. Stress-related dysbiosis leads to bacterial translocation and, as a result, increased susceptibility to infection. The frequency of sepsis is increasing despite progressive antibiotic therapy and implementation of infection control policies [19-22]. A global concern about antimicrobial resistances emphasizes the necessity of new strategies to reduce the risk of infections in surgical patients.

Probiotics, prebiotics, and synbiotics, a combination of the previous two, are nutritional adjuncts and emerge as new therapeutic options for the prevention of surgical infections. Probiotics have been shown to be useful in the treatment of gastrointestinal infections, acute infectious diarrhea in children, traveler's diarrhea, and antibiotic-associated diarrhea in both children and adults [23-34]. Mechanisms of action of probiotics include competitive exclusion of potentially pathogenic bacteria and direct antimicrobial effects, alteration of the $\mathrm{pH}$ of intestinal mucosa and prevention of bacterial translocation via tight junctions [35]. Furthermore, it has also been demonstrated that probiotics promote anti-inflammatory cytokine production [35]. Co-administration of prebiotics can enhance the proliferation of probiotic bacteria and certain bacterial genera can be stimulated selectively by these compounds.

There is a second important aspect with pro-/synbiotics in patients with chronic liver disease undergoing liver surgery: the crosstalk between the gut and its microbiota and the liver is increasingly recognized as so-called gut-liver axis. The gut and the liver communicate in a bidirectional way via the biliary tract, the portal venous system, and the systemic circulation, integrating signals generated by dietary, genetic, and environmental factors. The mucosa and vascular barrier of the intestine is the zone serving as a hub for the interactions between the gut and the liver, which is the central organ in host-metabolism. A dysbiosis with translocation of microbes and of microbial products when this barrier is disrupted may cause or worsen various hepatic diseases through this interdependence of gut and liver. Dysbiosis has been associated with many chronic liver conditions such as nonalcoholic fatty liver disease (NAFLD) or nonalcoholic steato-hepatitis (NASH), alcoholic liver disease (ALD), as well as cirrhosis and its complications like hepatic malignancy [36].

Current guidelines of the European Association for Study of the Liver (EASL) and the American Association for the Study of Liver Disease (AASLD) do not include pro-/synbiotics as part of the therapeutic protocol for LR and LT since their benefit is still under debate. Thus, a systematic review and meta-analysis was performed on the effects of pro-/synbiotic in liver surgery with a special focus on both infection and perioperative liver function.

\section{Methods}

\subsection{Literature Search Strategy}

A comprehensive systematic search of published articles on perioperative pro-/synbiotics in liver surgery from database inception to June 21, 2020, was performed using PubMed, CENTRAL and Embase (OvidSP). The search was carried out with the assistance of a librarian experienced in systematic reviews. A structured search strategy (File S1) was conducted with controlled vocabulary and relevant key terms to enhance sensitivity. The search strategy combined the following search terms: "probiotic OR probiot *", "synbiotic OR synbiot *" AND "operation * OR surgical procedure* OR liver surgery OR liver surg * OR liver transplantation * OR hepatectomy OR liver resection OR liver resect *" AND "mortality OR morbidity OR sepsis OR surgical infection * OR surgery site infection * OR post-operative wound infection * OR postoperative wound infection * OR complication *. In addition, reference lists of included papers and previous reviews were reviewed to identify potentially eligible studies. 


\subsection{Study Selection}

First, all abstracts identified by the search strategy after removal of duplicates were independently screened by two investigators (J.K., P.S.). If no abstract was available, the full text was obtained unless the article could be confidently excluded by title alone. Studies reporting on postoperative infection rate, which was the primary clinical efficacy outcome, or on parameters of liver function were considered. Randomized and non-randomized studies comparing perioperative administration of pro-/synbiotics in parallel groups were eligible. Case reports, case series, studies including children or animals, and in vitro studies were excluded.

Any disagreements during the screening process were resolved through discussion among the authors. We obtained the full texts of potentially eligible studies and again determined their suitability based on the selection criteria. Only full-text papers published in English were assessed.

\subsection{Data Extraction}

The following information was extracted from all studies: author, country, year of publication, study design, characteristics of the population studied, kind of liver surgery, number of study participants per group, time and duration of pro-/synbiotic administration, duration of follow-up, type of pro-/synbiotic used, infection rates and parameters of liver function.

\subsection{Quality Assessment}

The methodological quality of included randomized trials was evaluated with the Cochrane risk of bias assessment tool [37]. The methodological quality of the non-randomized studies included was assessed using the Newcastle-Ottawa Quality Assessment Scale for Cohort Studies [38].

\subsection{Data Synthesis}

We performed a random-effects meta-analysis with inverse variance weighting and the data are presented in forest plots. The risk ratio and the respective 95\% confidence interval (CI) for therapy and control groups in each study were estimated from the reported events. We performed subgroup analyses by type of liver surgery (LT or LR) and a sensitivity analysis including only randomized trials.

The analysis was performed using $\mathrm{R}$ version 3.6.1, in particular package "meta".

\section{Results}

\subsection{Literature Search}

The initial search identified 553 hits, 471 of which remained after the elimination of duplicates. A total of 426 publications were excluded during abstract screening. After the elimination of case reports $(n=2)$, animal studies $(n=3)$ and reviews $(n=28), 12$ studies met the inclusion criteria [39-50] (Figure 1). 


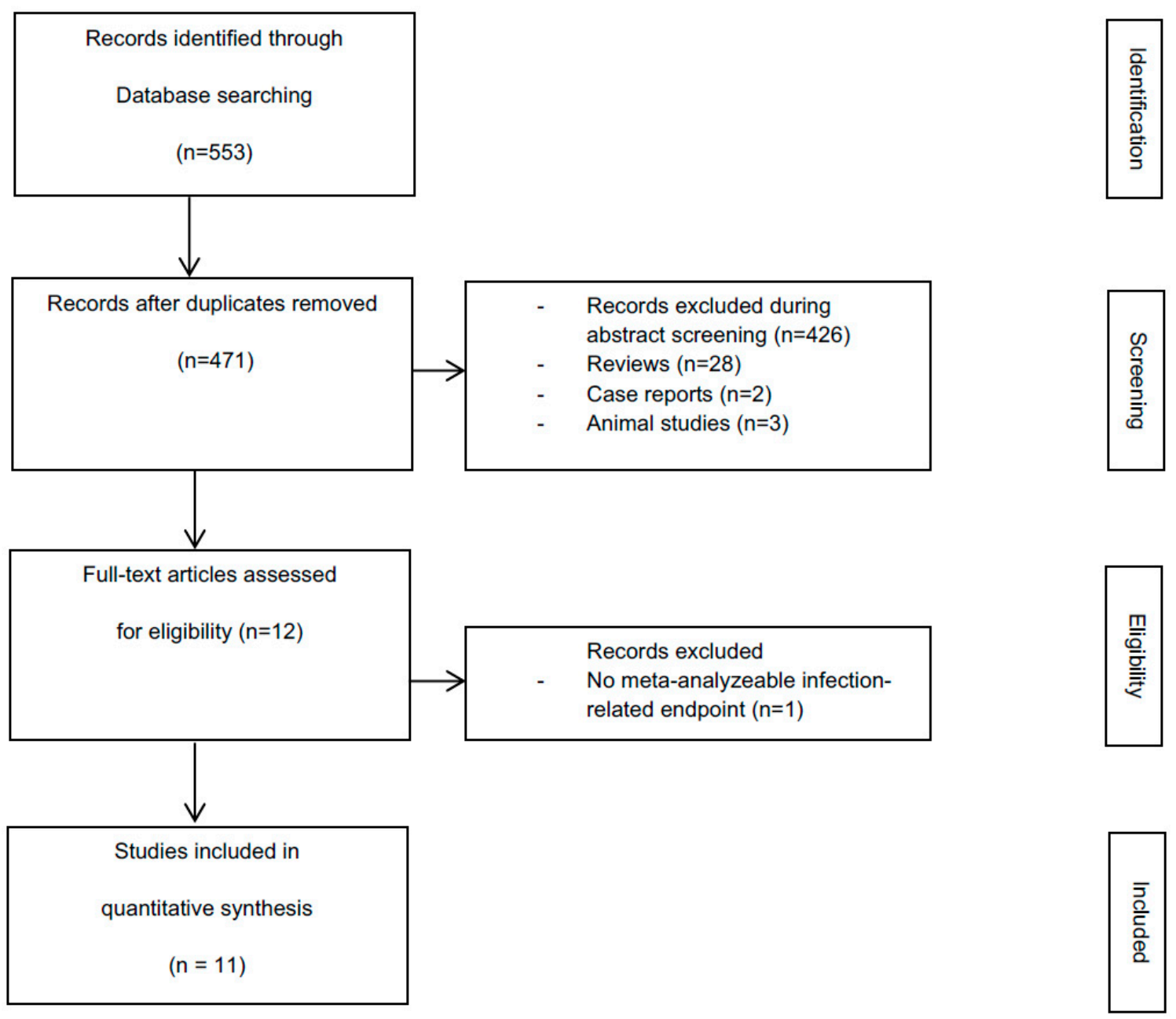

Figure 1. Flow chart depicting the screening and selection process for the systematic review of pro-/synbiotics on the prevention of infections and perioperative liver function.

\subsection{Study Characteristics}

Twelve studies were included in the systematic review (Table 1). They were published between 2005 and 2017. A total of 9 different pro-/synbiotics were used in these studies. Study sites were in Japan $(n=5)$, Germany $(n=3)$, Poland, Australia, Bosnia, and China. The mean duration of pro-/synbiotic administration was $18.75 \pm 9.75$ (range 7-70) days. In 2 studies [39,45], probiotics were used, while synbiotics were administered in 10 trials [40-43,46-49]. The most commonly utilized comparators were placebo $(n=5)[39-41,45,47]$ and no intervention $(n=5)[42,44,46,48,50]$. 
Table 1. Studies on perioperative pro-/synbiotics and their effect on postoperative infection.

\begin{tabular}{|c|c|c|c|c|c|c|c|c|c|c|}
\hline Study (Ref.) & Country & $\begin{array}{c}\text { Study } \\
\text { Population }\end{array}$ & $\begin{array}{l}\text { Pro-/Synbiotic }(n) / \\
\text { Control }(n)\end{array}$ & Pro-/Synbiotics Used & $\begin{array}{l}\text { Pro-/Synbiotic } \\
\text { Content and } \\
\text { Pharmaceutical Form }\end{array}$ & Control Used & Time of Administration & $\begin{array}{c}\text { Results } \\
\text { Pro-Synbiotic/Control } \\
\text { Postoperative } \\
\text { Infection Rate }\end{array}$ & $\begin{array}{l}\text { Age (Years) } \\
\text { All pt.; } \\
\text { Pro-/Synbiotic/ } \\
\text { Control }\end{array}$ & $\begin{array}{l}\text { Study } \\
\text { Design }\end{array}$ \\
\hline $\begin{array}{c}\text { Liver } \\
\text { transplantation } \\
\text { (LT) } \\
\end{array}$ & & $\begin{array}{c}\mathrm{PA} / \mathrm{PE} \\
n=290 / 343\end{array}$ & & & & & & & & \\
\hline $\begin{array}{c}\text { Rayes et al., } 2002 \\
{[40]}\end{array}$ & Germany & $63 / 105$ & $31 / 32$ & $\begin{array}{c}\text { Synbiotics } \\
\text { (Lactobacillus plantarum } 299 \text { and } \\
\text { inulin with selective bowel } \\
\text { decontamination and } \\
\text { enteric nutrition) }\end{array}$ & $\begin{array}{l}10^{9} \mathrm{CFU} \\
2 \times / \text { day }\end{array}$ & Placebo/inulin & $\begin{array}{l}\text { Just before LT until } \\
12 \text { days post LT } \\
\text { (13 days) }\end{array}$ & $\begin{array}{l}4 / 31,11 / 32 \\
\text { FU POD } 13\end{array}$ & $\begin{array}{l}50 \pm 2 ; \\
50 \pm 2 / \\
50 \pm 2\end{array}$ & RCT \\
\hline $\begin{array}{c}\text { Rayes et al., } 2005 \\
{[41]}\end{array}$ & Germany & $66 / 66$ & $33 / 33$ & $\begin{array}{c}\text { Synbiotics } \\
\text { (Pediococcus pentosaceus, } \\
\text { Leuconostoc mesenteroides, } \\
\text { L. paracasei, } 1010 \text { L. plantarum } \\
\text { 2362, beta-glucan, inulin, } \\
\text { pectin, and resistant starch and } \\
\text { enteric nutrition) }\end{array}$ & $\begin{array}{l}\text { probiotic: } 10^{10} \mathrm{CFU} \\
\text { prebiotic: } 10 \mathrm{~g} \\
2 \times / \text { day; } \\
\text { powder }\end{array}$ & Placebo/fibers & $\begin{array}{l}\text { Just after } \mathrm{LT} \text { until } \\
14 \text { days post LT } \\
\text { (13 days) }\end{array}$ & $\begin{array}{l}1 / 33,16 / 33 \\
\text { FU POD } 30\end{array}$ & $\begin{array}{l}51.5 \pm 2 \\
53 \pm 2 / \\
50 \pm 2\end{array}$ & RCT \\
\hline $\begin{array}{l}\text { Eguchi et al., } 2011 \\
\text { [42] }\end{array}$ & Japan & $50 / 50$ & $25 / 25$ & $\begin{array}{c}\text { Synbiotics } \\
\text { (Bifidobacte rium breve, } \\
\text { Lactobacillus casei, Galactooligo } \\
\text { saccharide and } \\
\text { enteric nutrition) }\end{array}$ & $\begin{array}{l}15 \mathrm{mg} \\
20 \mathrm{mg} \\
15 \mathrm{mg} \\
3 \times / \text { day }\end{array}$ & $\begin{array}{l}\text { No intervention, } \\
\text { enteric nutrition }\end{array}$ & $\begin{array}{l}2 \text { days prior to LDLT until } \\
14 \text { days post LDLT } \\
\text { (16 days) }\end{array}$ & $\begin{array}{l}1 / 25,6 / 25 \\
\text { FU POD } 19\end{array}$ & $\begin{array}{l}56.5 \pm \mathrm{NR} \\
56(33-66) / \\
57(25-68)\end{array}$ & RCT \\
\hline $\begin{array}{c}\text { Zhang et al., } 2013 \\
{[43]}\end{array}$ & Australia & $67 / 67$ & $34 / 33$ & $\begin{array}{c}\text { Synbiotics } \\
\text { (Lactobacillus acidophilus, } \\
\text { plantarum, lactis, casei, } \\
\text { rhamnosus, brevis, } \\
\text { Bifidobacterium lactis and fibers } \\
\text { and enteric nutrition) }\end{array}$ & $\begin{array}{c}15.5 \times 10^{9} ; 5.0 \times 10^{9} ; \\
2.0 \times 10^{9} ; 1.5 \times 10^{9} ; \\
1.5 \times 10^{9} ; 1.5 \times 10^{9} \\
\text { CFU; } \\
\text { capsules }\end{array}$ & $\begin{array}{l}\text { Enteric nutrition } \\
\text { and fibers }\end{array}$ & $\begin{array}{l}\text { Immediately after LT for } \\
7 \text { days at minimum } \\
\text { ( } 7 \text { days) }\end{array}$ & $\begin{array}{l}3 / 34,10 / 33 \\
\text { FU POD } 8\end{array}$ & $\begin{array}{l}56.01 \pm 10.98 \\
57 \pm 10 / \\
55 \pm 12\end{array}$ & RCT \\
\hline $\begin{array}{l}\text { Grat et al., } \\
2017 \text { [39] }\end{array}$ & Poland & $44 / 55$ & $21 / 23$ & $\begin{array}{l}\text { Probiotics (Lactococcus lactis, } \\
\text { Lactobacillus casei, } \\
\text { Lactobacillus acidophilus and } \\
\text { Bifidobacterium bifidum) }\end{array}$ & $\begin{array}{c}50 \% \\
25 \% \\
12.5 \% \\
12.5 \% \\
3 \times 10^{9} \mathrm{CFU} ; \text { capsules }\end{array}$ & Placebo & $\begin{array}{c}\text { Starting at the time of } \\
\text { wait-listing for LT until LT } \\
\text { Treatment duration for } \\
<2 \text { weeks, } 2-10 \text { weeks, } \\
\text { and }>10 \text { weeks in } 16.7 \%(4 / 24), \\
37.5 \%(9 / 24), \text { and } 45.8 \%(11 / 24) \\
\text { in the probiotic group and } \\
15.4 \%(4 / 26), 53.8 \%(14 / 26), \\
\text { and } 30.8 \%(8 / 26) \text { in the } \\
\text { placebo group }\end{array}$ & $\begin{array}{c}\text { 30-day infection rate } \\
0.09 \text { (95\%टCC 0.01-0.83) } \\
1 / 21,8 / 23 \\
90-\text { day infection rate } \\
0.06 \text { (95\%CC 0.01-0.48) } \\
1 / 21,11 / 23 \\
\text { FU POD } 90\end{array}$ & $\begin{array}{l}50.95 \pm \mathrm{NR} ; \\
52(47-58) / \\
50(35-61)\end{array}$ & RCT \\
\hline $\begin{array}{l}\text { Liver resection } \\
\text { (LR) }\end{array}$ & & $n=743 / 849$ & & & & & & & & \\
\hline $\begin{array}{l}\text { Kanazawa et al., } \\
2005 \text { [44] }\end{array}$ & Japan & $44 / 54$ & $21 / 23$ & $\begin{array}{l}\text { Bifidobacterium breve strain } \\
\text { Yakult, Lactobacillus casei strain } \\
\text { Shirota; prebiotic: galactooligo } \\
\text { saccharides }\end{array}$ & $\begin{array}{l}1 \times 10^{8} / \mathrm{g} \\
1 \times 10^{8} / \mathrm{g} \\
3 \mathrm{~g} / \text { day } \\
\text { prebiotic: } \\
12 \mathrm{~g} / \text { day } \\
\end{array}$ & $\begin{array}{l}\text { No intervention, } \\
\text { enteric nutrition }\end{array}$ & $\begin{array}{l}\text { Just after LT until } \\
14 \text { days post LT } \\
\text { (13 days) }\end{array}$ & $\begin{array}{l}4 / 21,12 / 23 \\
\text { FU POD } 30\end{array}$ & $\begin{array}{c}63.75 \pm 9.64 \\
62.5 \pm 9.9 / \\
64.9 \pm 9.4\end{array}$ & RCT \\
\hline
\end{tabular}


Table 1. Cont.

\begin{tabular}{|c|c|c|c|c|c|c|c|c|c|c|}
\hline Study (Ref.) & Country & $\begin{array}{c}\text { Study } \\
\text { Population }\end{array}$ & $\begin{array}{l}\text { Pro-/Synbiotic }(n) / \\
\text { Control }(n)\end{array}$ & Pro-/Synbiotics Used & $\begin{array}{c}\text { Pro-/Synbiotic } \\
\text { Content and } \\
\text { Pharmaceutical Form }\end{array}$ & Control Used & Time of Administration & $\begin{array}{c}\text { Results } \\
\text { Pro-Synbiotic/Control } \\
\text { Postoperative } \\
\text { Infection Rate }\end{array}$ & $\begin{array}{l}\text { Age (Years) } \\
\text { All pt.; } \\
\text { Pro-/Synbiotic/ } \\
\text { Control }\end{array}$ & $\begin{array}{l}\text { Study } \\
\text { Design }\end{array}$ \\
\hline $\begin{array}{l}\text { Liu et al., } \\
2015[45]\end{array}$ & China & $134 / 150$ & $66 / 68$ & $\begin{array}{l}\text { Lactobacillus plantarum, } \\
\text { Lactobacillus acidophilus, } \\
\text { Bifidobacterium longum }\end{array}$ & $\begin{array}{c}2.6 \times 10^{14} \mathrm{CFU} \\
2 \mathrm{~g} / \mathrm{day}\end{array}$ & Placebo & $\begin{array}{c}6 \text { days prior to } L R \text { until } \\
10 \text { days post } L R \\
\text { (16 days) }\end{array}$ & $\begin{array}{l}\text { 39/66, 60/68 } \\
\text { FU POD } 10\end{array}$ & $\begin{array}{l}62.84 \pm 17.17 \\
65.62 \pm 18.18 / \\
60.16 \pm 16.20 \\
\end{array}$ & RCT \\
\hline $\begin{array}{l}\text { Rayes et al., } \\
2012[47]\end{array}$ & Germany & $19 / 33$ & 9/10 & $\begin{array}{l}\text { Pediacoccus pentosaceus, } \\
\text { Leuconostoc mesenteroides } \\
\text { Lactobacillus paracasei } \\
\text { subspecies paracasei, } \\
\text { Lactobacillus plantarum; } \\
\text { prebiotic: bioactive fibers: } \\
\text { betaglucan, inulin, pectin, } \\
\text { and resistant starch }\end{array}$ & $\begin{array}{l}\text { probiotic: } 10^{10} \mathrm{CFU}, \\
\text { prebiotic: } 10 \mathrm{~g} \\
2 \times / \text { day; } \\
\text { powder }\end{array}$ & Placebo/fibers & $\begin{array}{l}1 \text { day prior to } L R \text { until } \\
10 \text { days post } \mathrm{LR} \\
\text { (11 days) }\end{array}$ & $\begin{array}{c}3 / 9,2 / 10 \\
\text { FU POD } 14\end{array}$ & $\begin{array}{c}60.05 \pm 13.89 \\
61 \pm 16 / 59 \pm 11\end{array}$ & RCT \\
\hline $\begin{array}{c}\text { Sugawara et al., } \\
2006[49]\end{array}$ & Japan & $81 / 101$ & $41 / 40$ & $\begin{array}{l}\text { Lactobacillus casei strain Shirota, } \\
\text { Bifidobacterium breve strain } \\
\text { Yakult; prebiotic: } \\
\text { galactooligosaccharides }\end{array}$ & $\begin{array}{c}\text { Pre-LR: } \\
4 \times 10^{10}, 80 \mathrm{~mL} \\
1 \times 10^{10}, 100 \mathrm{~mL} \\
\text { prebiotic: } \\
15 \mathrm{~g} 1 \times / \text { day } \\
\text { Post-LR: } \\
1 \times 10^{8} / \mathrm{g} \\
1 \times 10^{8} / \mathrm{g} \\
3 \mathrm{~g} / \text { day } \\
\text { prebiotic: } \\
10 \mathrm{~g} 1 \times / \text { day } \\
\end{array}$ & $\begin{array}{l}\text { No intervention, syn } \\
\text { biotics administered } \\
\text { only post LR }\end{array}$ & $\begin{array}{l}14 \text { days prior to } L R \text { and } \\
14 \text { days post } L R \\
\text { (28 days) }\end{array}$ & $\begin{array}{l}5 / 41,12 / 40 \\
\text { FU POD } 30\end{array}$ & $\begin{array}{l}63.15 \pm 8.84 \\
63.1 \pm 7.9 / \\
63.2 \pm 9.8\end{array}$ & RCT \\
\hline $\begin{array}{l}\text { Usami et al., } \\
2011 \text { [48] }\end{array}$ & Japan & $61 / 67$ & $32 / 29$ & $\begin{array}{l}\text { Lactobacillus casei strain Shirota, } \\
\text { Bifidobacterium breve strain } \\
\text { Yakult; prebiotic: } \\
\text { galactooligosaccharides }\end{array}$ & $\begin{array}{c}1 \times 10^{8} / \mathrm{g} \\
1 \times 10^{8} / \mathrm{g} \\
3 \mathrm{~g} / \text { day } \\
\text { prebiotic: } \\
10 \mathrm{~g} 1 \times / \text { day } \\
\end{array}$ & No intervention & $\begin{array}{l}14 \text { days prior to } L R \text { and } \\
11 \text { days post } L R \\
\text { ( } 25 \text { days) }\end{array}$ & $\begin{array}{c}0 / 32,5 / 29 \\
\text { FU POD } 30\end{array}$ & $\begin{array}{l}65.42 \pm 9.86 \\
62.1 \pm 10.2 / \\
69.1 \pm 8.0\end{array}$ & $\mathrm{RCT}$ \\
\hline $\begin{array}{l}\text { Rifatbegovic et al., } \\
\quad 2010[46]\end{array}$ & Bosnia & $120 / 120$ & $60 / 60$ & $\begin{array}{l}\text { Lactobacillus plantarum 2362, } \\
\text { L. paracasei subsp paracasei } 19, \\
\text { Pediacoccus pentoseceus 5-33:3 } \\
\text { and 32-77:1, L. raffinolactis } \\
\text { and fibers }\end{array}$ & NR & No intervention & $\begin{array}{c}3 \text { days prior to } L R \text { until } \\
7 \text { days post } L R \\
\text { (10 days) }\end{array}$ & $\begin{array}{c}\text { NR } \\
\text { FU POD } 14\end{array}$ & NR & $\begin{array}{l}\text { Prospective } \\
\text { non- } \\
\text { randomized, } \\
\text { NOS: } 7\end{array}$ \\
\hline $\begin{array}{l}\text { Iida et al., } \\
2020[50]\end{array}$ & Japan & $284 / 324$ & $115 / 169$ & Clostridium butyricum and fibers & $\begin{array}{l}6 \mathrm{~g} / \text { day } \\
12 \mathrm{~g} / \text { day }\end{array}$ & No intervention & $\begin{array}{l}30 \text { days prior to } L R \text { until } \\
1 \text { days prior to } L R \\
\text { (30 days) }\end{array}$ & $\begin{array}{l}\text { 19/115, 40/169 } \\
\text { FU POD } 3\end{array}$ & $\begin{array}{l}67.2 \pm \mathrm{NR} \\
68.2 \pm 11.6 / \\
66.2 \pm 12.6\end{array}$ & $\begin{array}{c}\text { Prospective } \\
\text { non- } \\
\text { randomized, } \\
\text { NOS: } 8\end{array}$ \\
\hline
\end{tabular}

LT, liver transplantation; LR, liver resection; LDLT, living donor liver transplantation; AST, aspartate-aminotransferase; ALT, alanine-aminotransferase; GLDH, glutamate-dehydrogenase; SSI, surgical site infection; FU, follow-up; POD, postoperative day; CFU, colony forming units; PA, patients analyzed; PE, patients enrolled. 


\subsection{Study Quality}

The study quality of the two non-randomized studies according to the Newcastle-Ottawa scale was 7 (out of a maximum of 9) and 8 points. The methodological quality of the 10 included randomized studies is presented in a risk of bias summary (Figure 2). As summarized there, the methodological quality was moderate; performance bias was detected in $10 \%$, detection bias also in $10 \%$, selection bias in $10-20 \%$, attrition bias in $30 \%$ of the analyzed RCTs, whereas reporting bias was detected in $40 \%$.
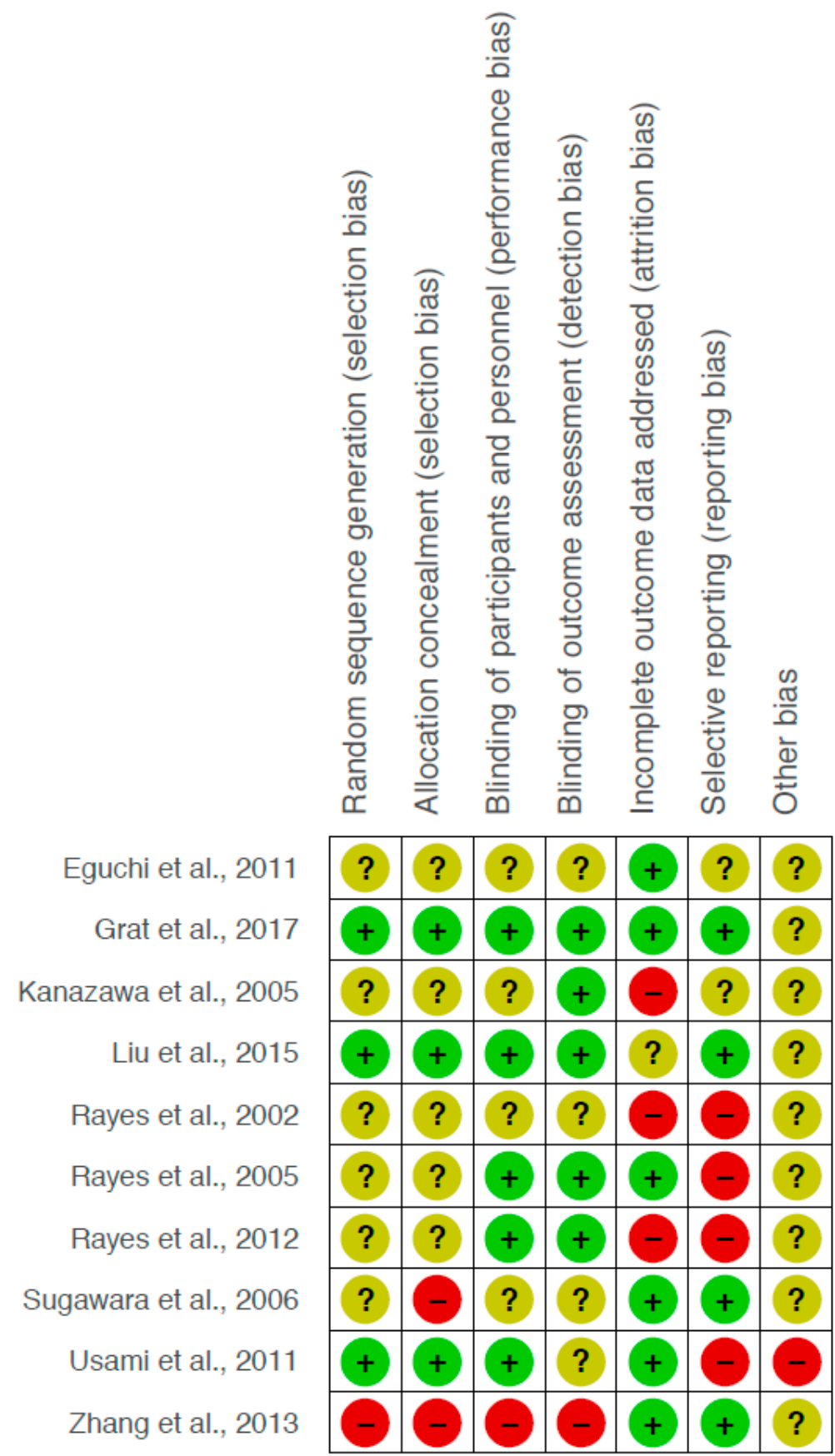

Figure 2. Risk of bias summary: review of authors' judgement on the risk of bias for the analyzed randomized controlled trials. Red circle symbolizes high risk of bias, green circle symbolizes low risk of bias, yellow circle symbolizes unclear risk of bias. 


\subsection{Infection Rate after Liver Transplantation}

To date, a total of 5 studies, all of which were RCTs, have elucidated the mechanism of how intestinal microbiota influence the course after LT (Table 1). These studies primarily focused on infectious complications after LT. Four of these studies reported primarily post-transplant application of synbiotics [51]. One LT study reported pre-transplant synbiotic treatment starting at the time of wait-listing for LT and focused on the pre- and post-transplant patient outcomes including the development of the severity of liver disease pre-transplant, as assessed by the model of end-stage liver disease (MELD)- and Child Turcotte Pugh (CTP) scores and liver function post-transplant [39].

Rayes et al. compared the synbiotic Lactobacillus plantarum 299 and inulin (group 1) with selective bowel decontamination (group 2) and inulin with heat-killed Lactobacillus plantarum 299 (placebo, group 3) in 95 LT patients (31 patients in group 1, 32 patients in group 2, 32 patients in group 3) [40]. The lowest infection rates were shown with synbiotic treatment (13\% vs. 48\% (selective bowel decontamination), $p=0.017$, and 34\% (inulin alone)). Most infections were caused by enterogenic bacteria (Salmonella, Yersinia, Campylobacter). Synbiotic 2000 was compared with a placebo containing only fibers in 66 (33/33) LT patients by Rayes et al. [41]. Significantly less bacterial infections occurred in the synbiotic group ( $3 \%$ vs. $48 \%$ ). Patients in the synbiotic group were treated with antibiotics for a significantly shorter time $(0.1 \pm 0.1$ days as compared to $3.8 \pm 0.9$ days $)$. No severe adverse events occurred in both groups, and no infections were caused by prebiotics. Eguchi et al. compared synbiotics (Bifidobacterium breve, Lactobacillus casei, Galactooligosaccharide) with no therapy in 50 patients undergoing living donor liver transplantation (LDLT) [42] and reported significantly reduced infection rates. In the study of Zhang et al., synbiotics (Bifidobacterium lactis, Lactobacillus acidophilus, casei, rhamnosus, brevis, lactis, plantarum and fibers and enteral nutrition) were compared with enteral nutrition and fibers in 50 LT patients [43]. This study reported significantly lower bacterial infection rates within the synbiotic group $(8.8 \%$ vs. $30.3 \%, p=0.030)$. Grat et al. investigated the difference between probiotics and placebo, their administration starting at the time of wait-listing for LT in 55 patients (28 patients in probiotics group, 27 patients in placebo group) [39]. Treatment durations for $<2$ weeks, $2-10$ weeks and $>10$ weeks were reported in $16.7 \%(4 / 24), 37.5 \%(9 / 24)$, and $45.8 \%(11 / 24)$ in the probiotic group and in $15.4 \%(4 / 26), 53.8 \%(14 / 26)$, and $30.8 \%(8 / 26)$ in the placebo group $(p=0.52)$. There was no difference in mortality rates but significantly lower infection rates in the probiotic group: 30-day-infection rate of $4.8 \%$ vs. $34.8 \%$ ( $p=0.020), 90$-day-infection rate of $4.8 \%$ vs. $47.8 \%(p=0.002)$.

\subsection{Infection Rate after Liver Resection}

To date, only 7 studies have elucidated the mechanism of how intestinal microbiota influence the course after LR. Five of them were RCTs [44,45,47-49], and 2 were prospective non-randomized trials (Table 1) [46,50]. Most of the studies also focused primarily on postoperative infectious complications, which lead to increased morbidity and mortality, and also to high treatment costs. They further focused on intestinal integrity, microflora, and surgical outcomes [44,45], serum zonulin levels and intestinal integrity, systemic inflammatory response, microflora and surgical outcome, perioperative development of liver function and postoperative complications in one study [46], as well as liver regeneration after LR in one study [47]. Pro-/synbiotics were administered before and after LR in 5 of the studies, only post LR in 1 study [44], and only prior to surgery in 1 study [51]. The duration of pro-/synbiotic administration was between 1 and 14 days prior to LR, and 6 and 14 days following LR and for 1 month in the study with only preoperative administration [50]. Liu et al. compared probiotic vs. placebo in their double-blind RCT in 66 vs. 68 patients undergoing LR for colorectal metastases [45]. Lower infection rates were reported in the therapy group ( $p=0.008)$, as well as lower endotoxin $(p<0.001)$ and zonulin levels $(p=0.004)$. Kanazawa et al. compared Yakult BL Seichoyaku and Galacto-oligosaccharides vs. no therapy in 44 (21 synbiotic group, 23 control group) patients undergoing LR [44]. All patients underwent hemihepatectomy or more extensive resection with en bloc resection of the caudate lobe and the extrahepatic bile duct. Combined vascular resection with reconstruction was performed in 7 patients in each of the two groups. Baseline characteristics were 
matched between the two groups [44]. Lower infection rates were reported in the synbiotics group (52.2\% vs. $19 \%, p=0.031)$. Usami et al. [48] also investigated infection rates in patients undergoing LR, either receiving synbiotic or no therapy, which were 0/32 in the synbiotic group and 5/29 (17.2\%) in the control group. Rayes et al. compared prebiotic (beta-glucan, inulin, pectin, and resistant starch) with synbiotic (P. pentosaceus, L. mesenteroides, L. plantarum, L. paracasei, and beta-glucan, inulin, pectin, and resistant starch) in 19 patients (9 synbiotic group, 10 control group) [47]. Three of the patients in the synbiotic group and 2 of the control patients had an infectious complication.

Rifatbegovic et al. investigated patients with liver cirrhosis and histologically verified hepatocellular carcinoma (HCC) undergoing LR (segmentectomy/bisegmenctetomy, right and left hemihepatectomy/extended hemihepatectomy). They compared 60 patients with preoperative and postoperative use of synbiotics (Lactobacillus plantarum, L. paracasei subsp paracasei, Pediacoccus pentoseceus, L. raffinolactis and fibers) with 60 patients without synbiotic therapy [46]. Total protein and albumin were significantly higher in the synbiotic group. CRP, IL-1, IL-6, and TNF on post-operative days (POD) 7 and 14 were reported to be significantly lower in patients who used the synbiotic. The incidence of early and late post-operative complications after LR in the probiotic group was significantly smaller as compared with the control group (13.89 vs. $33.33 \%, p<0.0001$, and 8.33 vs. $19.44 \%, p<0.001)$, and lower short-term and long-term mortality $(8.33 \%$ vs. $2.78 \%, p<0.02,5.56 \%$ vs. $13.89 \%, p<0.01)$ and significantly higher survival rates ( 86.11 vs. $66.67 \%)$ in the synbiotic group were reported in this study [46].

Sugawara et al. compared synbiotic use (Lactobacillus casei strain Shirota, Bifidobacterium breve strain Yakult as well as prebiotic galactooligosaccharides) 14 days preoperatively and 14 days postoperatively with only postoperative administration in 81 patients undergoing liver and extrahepatic bile duct resection with hepaticojejunostomy for perihilar cholangiocarcinoma [49]. Pre- and postoperative IL 6 levels were significantly lower, and the incidence of postoperative infectious complications was $30.0 \%$ vs. $12.1 \%(p=0.049)$ in the group receiving the synbiotic pre- and postoperatively. Iida et al. investigated the influence of 1-month preoperative synbiotic therapy as compared with no intervention on infectious complications in 284 LR patients ( $n=115$ in synbiotic group, $n=169$ in control group) [50]. They found no difference regarding infection rates after LR between the groups.

\subsection{Meta-Analysis on Infection Rates}

Risk ratios for infection rates of all patients receiving pro-/synbiotics perioperatively vs. controls were stratified by type of surgery (LT vs. LR) and displayed in a forest plot (Figure 3). Four studies (2 LT and 2 LR studies) found a significant difference between the groups [41,43-45], 1 LT study showed a trend favoring perioperative pro-/synbiotic use to reduce infection rates postoperatively [39]. 


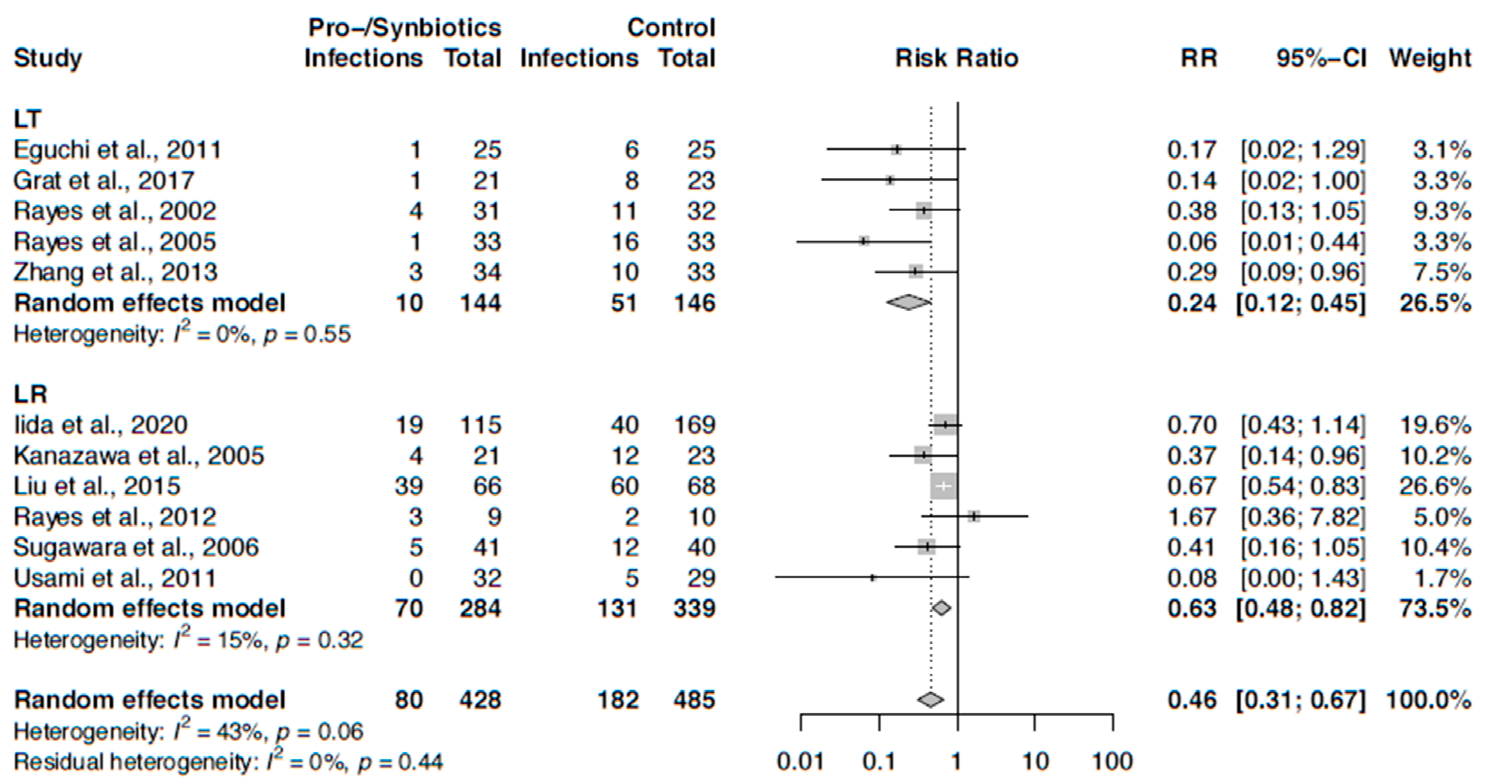

Figure 3. Forest plot of trials on perioperative pro-/synbiotics and their effect on infection stratified by type of surgery: liver resection (LR), liver transplantation (LT).

Pooling the results for infection rates from studies of both study designs in a meta-analysis, pro-/synbiotics showed a significant lower infection rate (RR 0.46, 95\% CI: 0.31-0.67). However, there was moderate heterogeneity $\left(\mathrm{I}^{2}=43 \%, p=0.06\right)$. When stratifying by LR or LT, both subgroups showed a benefit of pro-/synbiotics, but the effect was stronger in LT patients than in LR patients (Figure 3). Furthermore, residual heterogeneity was insubstantial. We also performed a sensitivity analysis including only RCTs, where one study was excluded. The results were very similar (Figure 4).

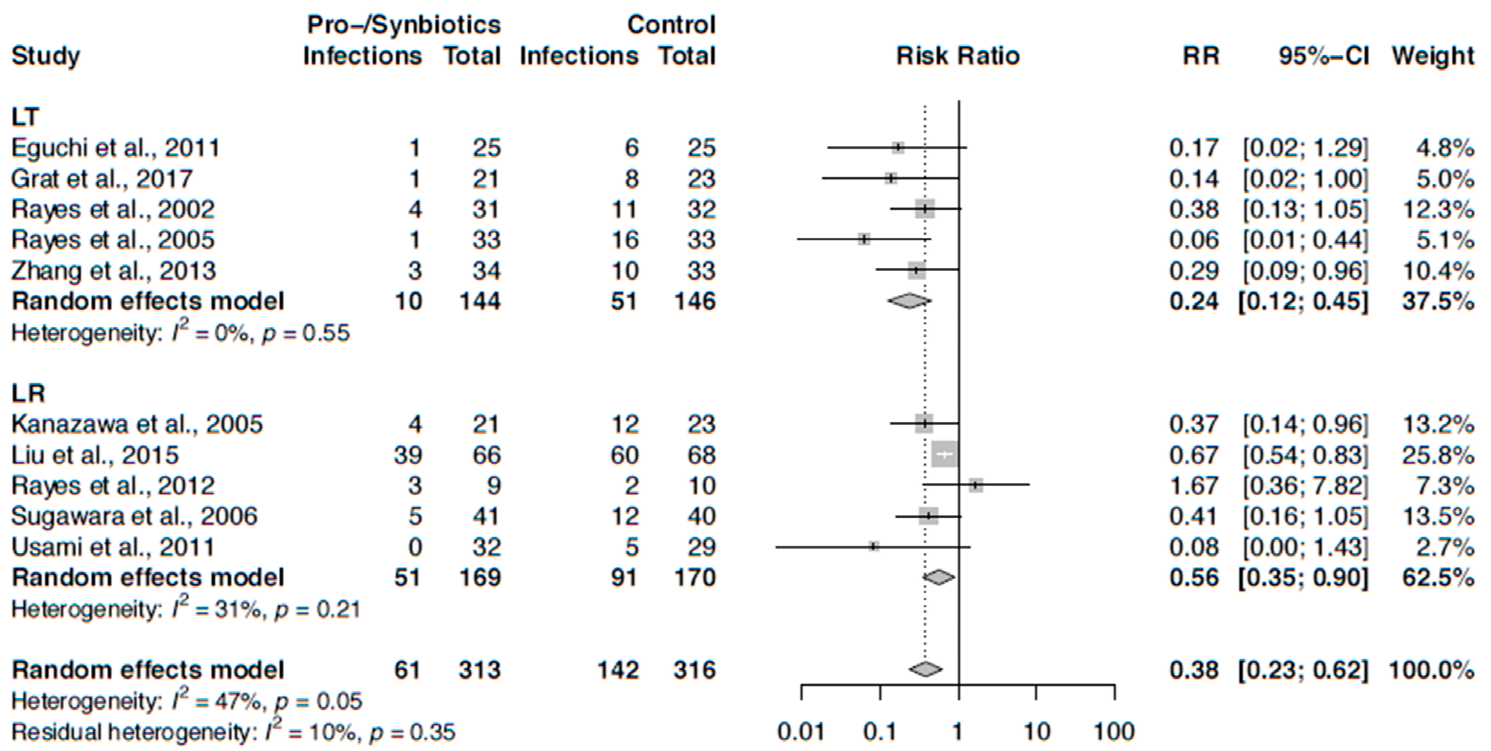

Figure 4. Forest plot of randomized controlled trials on perioperative pro-/synbiotics and their effect on infection stratified by type of surgery: liver resection (LR), liver transplantation (LT).

A meta-regression for mean age of study participants and duration of supplementation, adjusted for type of surgery, showed no significant influence of these covariates $(p=0.766$ and $p=0.721$, respectively). 


\subsection{Perioperative Liver Function Parameters in LT}

Only 3 of the 5 LT studies reported perioperative liver function, with 1 study showing a significantly faster decrease of aspartate aminotransferase (AST) and alanine aminotransferase (ALT) after LT (Table 2) [39]. Rayes et al. reported no difference in bilirubin, AST, ALT, gamma glutamyl transferase (GGT), alkaline phosphatase (AP) after LT between the groups [40], no difference in laboratory markers of liver function, and also no difference in acute rejection rates [41]. Liver function was not reported in the studies by Eguchi et al. [42] and Zhang et al. [43]. Grat et al. [39] reported postoperative bilirubin levels to be significantly lower in the probiotics group $(p=0.020)$. The postoperative decrease of both AST and ALT activity was faster $(p=0.030)$, and international normalized ratio (INR) values were non-significantly lower in the probiotic group. There was one case of primary non-function (PNF) in the placebo group ( $4.3 \%)$ and no such case in the probiotic group $(0.0 \%$, n.s.) There was no waiting list mortality. In the placebo group, the MELD score significantly decreased from a median of 13 to 12.5 over the entire pre- transplant assessment period $(p=0.040)$. In the probiotic group, the MELD score changes were not significant. However, there was no significant difference in the MELD score change between the groups. No significant change in the CTP class over the entire period was noted in both the probiotic and placebo groups.

Table 2. Studies on perioperative pro-/synbiotics and their effect on liver function.

\begin{tabular}{|c|c|c|c|}
\hline Study (Ref.) & $\begin{array}{c}\text { Results } \\
\text { Pro-Synbiotic/Control } \\
\text { Perioperative Liver Function }\end{array}$ & $\begin{array}{l}\text { Assessment of } \\
\text { Liver Function }\end{array}$ & Study Design \\
\hline \multicolumn{4}{|l|}{ Liver Transplantation (LT) } \\
\hline Rayes et al., 2002 [40] & No difference AST, ALT, GGT, AP & FU POD 13 & RCT \\
\hline Rayes et al., 2005 [41] & No difference AST, ALT, GGT, AP & FU POD 30 & RCT \\
\hline Grat et al., 2017 [39] & $\begin{array}{c}\text {-ALT (IU/l) } 398.8 \pm 307.68 / 441.05 \pm 432.72 \\
\text {-AST (IU/l) } 140.4 \pm 123.59 / 105.6 \pm 62.92 \\
\text {-Bili (mg/dl) } 2.5 \pm 1.91 / 2.9 \pm 2.59 \\
\text {-INR } 1.05 \pm 0.10 / 1.16 \pm 0.18\end{array}$ & FU POD 5 & $\mathrm{RCT}$ \\
\hline \multicolumn{4}{|l|}{ Liver Resection (LR) } \\
\hline $\begin{array}{l}\text { Liu et al., } \\
2015 \text { [45] }\end{array}$ & $\begin{array}{l}\text {-ALT (U/1) } 32.62 \pm 18.86 / 35.68 \pm 15.26 \\
\text {-AST (U/1) } 28.22 \pm 18.86 / 29.68 \pm 16.56 \\
\text {-ALT (U/1) 36.28 } \pm 18.92 / 56.20 \pm 18.16 \\
\text {-AST (U/1) } 36.18 \pm 21.52 / 45.62 \pm 22.68\end{array}$ & $\begin{array}{l}\text { Prior to LR } \\
\text { FU POD } 10\end{array}$ & RCT \\
\hline Rayes et al., 2012 [47] & 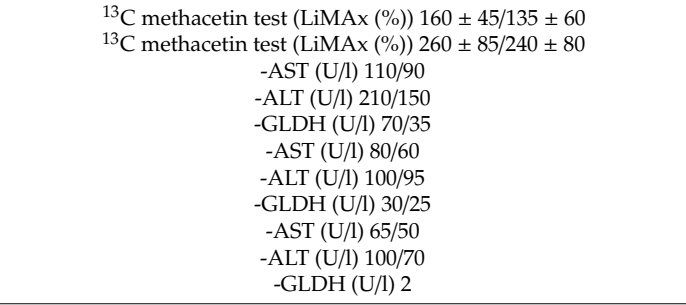 & $\begin{array}{l}\text { FU POD } 5 \\
\text { FU POD } 14 \\
\text { FU POD } 5 \\
\text { FU POD } 10 \\
\text { FU POD } 14\end{array}$ & RCT \\
\hline Usami et al., 2011 [48] & No difference AST, ALT, bilirubin & FU POD 15 & RCT \\
\hline Rifatbegovic et al., 2010 [46] & $\begin{array}{c}\text {-ALT (U/l) } 50 \pm 5 / 68 \pm 7 \\
\text {-Bili (mcmol/l) } 17 \pm 0.8 / 31.3 \pm 1.5 \\
\text {-Indocyaningreen test 1.15/1.425 }\end{array}$ & FU POD 14 & $\begin{array}{c}\text { Prospective } \\
\text { non-randomized, } \\
\text { NOS: } 7 \\
\end{array}$ \\
\hline Iida et al., 2020 [50] & $\begin{array}{c}\text { PostLR liver failure (grade) } \\
\text {-A: } 8 / 115,13 / 169 \\
- \text { B: } 1 / 115,16 / 169 \\
\text {-C: } 1 / 115,4 / 169 \\
23(16,31)-20(13,34) \\
\text {-ALT (IU/l) prior to synbiotic-after synbiotics }(n=115) \text { : } \\
\text {-AST (IU/l) prior to synbiotics-after synbiotics }(n=115) \text { : } \\
27(22,43)-26(20,34) \\
\text {-Bilirubin }(\mathrm{mg} / \mathrm{dl}) \text { prior to synbiotics-after synbiotics }(n=115) \text { : } \\
0.7(0.5,0.8)-0.6(0.4,0.8) \\
\text { Prothrombin activity }(\%) \text { prior to synbiotics-after synbiotics }(n=115) \text { : } \\
96(87,109)-96(85,103)\end{array}$ & FU POD 3 & $\begin{array}{l}\text { Prospective } \\
\text { non-randomized, } \\
\text { NOS: } 8\end{array}$ \\
\hline
\end{tabular}

Data are expressed as mean \pm standard deviation (SD) [39,45-47], median (interquartile range) [50]; LT, liver transplantation; LR, liver resection; LDLT, living donor liver transplantation; AST, aspartate-aminotransferase; ALT, alanine-aminotransferase; GLDH, glutamate-dehydrogenase; SSI, surgical site infection; FU, follow-up; POD, postoperative day; LiMAx, maximum liver function capacity; Characteristics of studies as defined in Table 1. 


\subsection{Perioperative Liver Function Parameters in LR}

Liu et al. reported that both ALT and AST levels as measured on POD 10 were significantly lower with synbiotics. ALT levels (U/L) were $56.20 \pm 18.16$ in the control group vs. $36.28 \pm 18.92$ in the synbiotic group ( $p<0.001)$; AST levels (U/L) were $45.62 \pm 22.68$ vs. $36.18 \pm 21.52(p<0.015)$ (Table 2) [45]. Kanazawa et al. reported no difference with respect to postoperative serum total protein and serum total bilirubin levels between the 2 groups [44]. Usami et al. reported that total bilirubin, AST, and ALT were increased on POD 1-3 but returned to preoperative values by POD 13-15 in both groups, showing no difference between the groups (31 patients with synbiotics had a CTP score C in this study, and 28 patients in the control group, 1 patient each, had a CTP score B, and none CTP A) [48], but there was a trend toward higher levels of AST and ALT with synbiotics, which could partly be explained by longer operation times and more blood loss during surgery with synbiotics. Rayes et al. reported perioperative liver function capacity as measured by the ${ }^{13} \mathrm{C}$ methacetin breath test and indocyanine green plasma disappearance rate, which was comparable in both groups. Complications had a negative impact on liver function, and complications were more severe in the synbiotic group in this study (Table 1; higher transaminases in the synbiotic group) [47]. Rifatbegovic et al. reported that AST, ALT, alkaline phosphatase (AP), and GGT preoperatively, on POD 7 and 14 with synbiotics for 10 days was significantly lower than in controls. Cholinesterase and total cholesterol did not differ between the groups; total and conjugated bilirubin was significantly lower with synbiotics. Perioperative liver function parameters were not reported in Sugawara's study [38]. In Iida's study, ALT, AST, total bilirubin, and prothrombin activity were measured before and after synbiotics-directly prior to surgery, after 30 days of synbiotics. Only patients with synbiotics $(n=115)$ were analyzed and have shown no difference in liver function after 1-month treatment with synbiotics as compared to the values before synbiotics (Table 2) [50]. Studies on perioperative pro-/synbiotics and their effect on changes of the gut microbiota are shown in Table 3.

Table 3. Studies on perioperative pro-/synbiotics and their effect on changes of the gut microbiota.

\begin{tabular}{|c|c|}
\hline Study (Ref.) & Gut Microbiota Changes \\
\hline \multicolumn{2}{|l|}{ Liver Transplantation (LT) } \\
\hline Eguchi et al., 2011 [42] & $\begin{array}{l}\text { No significant changes between the groups } \\
\text { Enterococcus sp. evident in both groups in } 25 \% \text { of the } \\
\text { immunosuppressed patients }\end{array}$ \\
\hline Grat et al., 2017 [39] & $\begin{array}{l}\text { Probiotic group: Bacteroides sp. }(p=0.008), \text { Enterococcus sp. }(p=0.04) \\
\text { significantly increased in comparison to pre-trial values as compared to } \\
\text { control group }\end{array}$ \\
\hline \multicolumn{2}{|l|}{ Liver Resection (LR) } \\
\hline Kanazawa et al., 2005 [44] & $\begin{array}{c}\text { Synbiotic group: Lactobacillus and Bifidobacterium increased } \\
\text { postoperatively in comparison to controls }(p<0.05) \\
\text { Control group: Enterobacteriaceae, Pseudomonas, Candida increased in } \\
\text { comparison to synbiotic group }(p<0.05) \\
\text { Enterococci increased postoperatively in both groups }\end{array}$ \\
\hline Sugawara et al., 2006 [49] & $\begin{array}{l}\text { Pre-and post-operative probiotic group: Bifidobacterium significantly } \\
\text { increased after preoperative treatment }(p<0.05) \\
\text { Anaerobic bacteria numbers were unchanged before and after surgery } \\
\text { between the two groups }\end{array}$ \\
\hline Usami et al., 2011 [48] & $\begin{array}{c}\text { Bacteroidaceae, Bifidobacterium decreased, Candida increased } 1 \text { week } \\
\text { postoperatively, resembled preoperative values after } 2 \text { weeks } \\
\text { No differences concerning liver function }\end{array}$ \\
\hline
\end{tabular}




\section{Discussion}

Surgical stress-related dysbiosis leads to bacterial translocation resulting in a limited detoxification function of the liver being the central hub of the gut-liver axis, increased susceptibility to infections, and worse outcome. After liver surgery, about 30\% of the patients develop a bacterial infection, and if bacteremia occurs, the risk of liver failure increases to over 50\% and mortality to over $40 \%[1,14,15]$.

Following surgery, systemic endotoxinemia is facilitated for the following reasons: the presence of aerobic and anaerobic microflora through the entire gastrointestinal tract, microvascular damage and diminished gut integrity resulting from ischemia/reperfusion injury, compromised and altered immunity, secondary to the inflammatory cascade, the duration of visceral ischemia (necrosis occurs much faster in intestinal mucosa than in other tissues), and the presence of hemorrhage and hypotension. Under these circumstances, the occurrence of transient endotoxinemia is almost certain, with infectious and non-infectious postoperative complications as possible consequences.

Unfortunately, postoperative infectious and non-infectious complications do occur in spite of preventive treatment with antibiotics immediately before or during surgical treatment and have so far been treated upon their occurrence during the postoperative recovery period.

Inflammation is normally a local and temporary event, which is restored upon its resolution. However, disrupted immune regulation can result in continuous pro-inflammatory cytokine activity and excessive or chronic inflammation. Sepsis is induced by an excessive response of the immune system to microorganisms or their products. LPS is a powerful activator of the innate immune system and interacts with macrophages, monocytes, neutrophils, and endothelial cells, which results in the rapid release of many pro- and anti-inflammatory mediators. LPS is the pivotal initiator of gram-negative sepsis, and the involvement of different receptors in this process has been demonstrated in various studies [52,53]. Intervening with this initiator by detoxification or neutralization therefore seems rational. It was shown that the enzyme alkaline phosphatase (AP) detoxifies LPS through dephosphorylation in vivo. In the liver, LPS can be inactivated and the initiation of inflammatory processes inhibited by activation of the enzyme AP by special bacterial strains (e.g., Lactococcus lactis W19).

The main functions of probiotics, pre-/synbiotics are the implementation of colonization resistance to pathogenic germs, improvement of bowel motility and splanchnic blood flow, the stimulation of enterocyte growth and mucus formation, modulation of intestinal inflammation, stabilization of the intestinal barrier, and stimulation of the immune system and also non-immune mechanisms through competition with potential pathogens [43]. A modulation of the intestinal functions of the immune system in the sense of reduction of pro-inflammatory cytokines, favoring tolerance-inducing cytokine profiles and regulatory pathways and an increase of the secretory IgA, is one of the multiple effects of probiotics. Epithelial cell homeostasis is promoted by increasing the barrier function, promoting cytoprotective responses, improving cell survival, and increasing mucin production. The effect of pathogenic germs is blocked by reducing the binding to the mucosa, lowering the $\mathrm{pH}$ in the lumen, and the production of antibacterial bacteriotoxins. It brings nutritional benefits by helping to break down otherwise indigestible food components and unlocking nutrients. Probiotics also have an impact on neuromodulation by expressing cannabinoid and $\mu$-opioid receptors on the epithelial cells. This mechanism of action has been observed in Lactobacillus acidophilus, and these findings are based on murine models and evidence in humans is still lacking [54]. Apart from that, they reduce visceral hypersensitivity and the stress response. Of course, there is stress not only in the conventional sense but in connection with surgical interventions as a so-called "surgical stress reaction" [55].

A recent systematic review and meta-analysis on the effects of perioperative pro-/synbiotics in adults undergoing elective abdominal surgery by Chowdhury et al. showed that the perioperative administration of either probiotics or synbiotics significantly reduced the risk of postoperative infectious complications (relative risk (RR) 0.56; 95\% confidence interval (CI) $0.46-0.69 ; P<0.0001$ ) [56]. Synbiotics showed greater effect on postoperative infections compared with probiotics alone (synbiotics RR: 0.46; 95\% CI: 0.33-0.66; $P<0.0001$, probiotics RR: 0.65; 95\% CI: 0.53-0.80; $P<0.0001)$. Synbiotics but not probiotics also led to a reduction in total length of stay. There were no significant differences in mortality 
or non-infectious complications between groups [56]. Another review made similar observations that pro-/synbiotics counteract surgical site infections (SSIs) and surgically related complications (SRCs) via modulating the gut-immune response and via the production of short chain fatty acids [57]. A previous review by Moran et al. 2012 had shown no significant benefit of synbiotics in elective abdominal surgery, but patients undergoing hepatopancreatobiliary surgery or LT showed significantly reduced postoperative infectious complications [58].

Here, we focus on liver surgery. The stage of malnutrition as risk factor for postoperative complications and infections is common in patients with liver cirrhosis undergoing LR or LT [59]. A crosstalk between gut and liver is generally recognized [60], where intestinal dysbiosis and increased permeability of the intestine lead to microbial overgrowth and increased translocation of bacteria and fungi as well es their products like endotoxins from gram-negative bacteria and beta-glucans from fungi into the portal venous system. In the liver, they are recognized by Kupffer cells and stellate cells and are directly inactivated under normal conditions. Under pathological conditions when the intestinal barrier is impaired with an increased translocation of microbial products, an inflammatory process is initiated leading to liver damage impairing hepatocyte function and detoxification potential, which may lead to inflammatory liver diseases. Lipopolysaccharides (LPS) trigger toll-like receptor 4 (TLR4) expressed by Kupffer and hepatic stellate cells to activate transforming growth factor $\beta$ signaling that leads to the development of hepatic fibrosis and eventually cirrhosis [36]. In end-stage liver disease, microbial products that cannot be cleared by the liver get into the systemic circulation, activating immune cells and leading to damage of distant organs. Endotoxinemia primes neutrophils with development of small amounts of reactive oxygen species increasing bacterial clearance. Chronic over-stimulation can lead to exhaustion and reduction of phagocytic capacity and oxidative burst and increased infection rates. Bacterial infections in general are common complications resulting from impaired immune responsiveness.

Synbiotics in cirrhotic patients were reported to significantly decrease ammonia and serum endotoxin levels, as well as prevention of cecal overgrowth with Escherichia coli and Staphylococcus sp. It was also reported to lead to reversal of minimal hepatic encephalopathy and improvement of liver function in half of the patients. Fermentable fibers alone were also effective in some patients according to a study by Liu et al. [61].

A prospective randomized placebo-controlled, double-blind study was conducted at the Medical University Clinic of Graz; here, non-surgical patients with liver cirrhosis taking synbiotics were shown to have better liver function and less susceptibility to infection [62]. Liver function significantly improved as measured by the most common liver function scores (CTP (Child Turcotte Pugh) score, model of end stage liver disease (MELD) score) with synbiotics as compared with the placebo group, although the function of the verum group at the beginning of the study was significantly worse. The infection rate with synbiotics was significantly lower than in controls. The tolerance and the compliance were excellent, and no interactions with other drugs were reported.

Only 1 of the LT studies reported a significant faster postoperative decrease of bilirubin levels with probiotics $(p=0.020)$, postoperative decrease of AST and ALT activities $(p=0.030)$, as well as faster improvement of liver synthesis parameters with lower INR values. They also reported the dynamics of the MELD and CTP scores of the patients on the waiting list, which showed no difference between the groups. This study by Grat et al. investigated preoperative probiotics from the time of wait-listing for LT on [39]. Two LT studies by Rayes et al. reported no difference regarding parameters of liver synthesis and liver function in LT patients; the administration time frames were between pre-transplant day 1 and post-transplant day 12, as well as post-transplant day 1 and 14. The 2 other LT studies did not report liver function.

The incidence of postoperative infections is high in cirrhotic patients undergoing LR for liver tumors. Bacterial translocation after LR in patients with liver cirrhosis has been reported to occur in mesenteric lymph nodes in $20 \%$ [63], $44 \%$ of those patients with positive lymph nodes developed 
infectious complications, and $88 \%$ of the cases with infectious complications indicated the same bacterial species as the lymph node cultures.

The risk of infection is even higher after LT because of immunosuppression. A recent study on SSIs after LT [64] clarifies the explosiveness of this topic with a percentage of 53\% infections that are caused by multi-resistant germs with significantly higher mortality after LT. The origin of deep SSI was abscesses in $58 \%$, a peritonitis in $28 \%$, deep wound infections in $8 \%$ and a cholangitis in $6 \%$. An increase of 24 hospital days per patient, 159.967 US\$ extra costs and a 10\% higher mortality was reported. In LT, especially, other factors like malnutrition, ischemia-reperfusion injury, and immunosuppressive therapy may lead to dysbiosis, disrupted intestinal barrier, alterations in the innate immunity response, and bacterial translocation. This can be associated with early infections, graft failure, and decreased survival [60]. Due to a dysbiosis with a decrease of beneficial bacteria and an increase of pathogenic species, the response to the host consists of higher endotoxin levels and increased bacterial translocation. Previous studies suggest that the intestinal microbiota regulate liver tumorigenesis or inflammatory reactions through altering the activity of pro-inflammatory microorganism-associated molecular patterns, bacterial metabolites, natural killer (NK) T cells-mediated bile acid metabolism, and prostaglandin (PG)E2- mediated suppression of antitumor immunity [61,63-65]. In the liver, lipopolysaccharides (LPS) can be inactivated by activation of the enzyme alkaline phosphatase by special bacterial strains (e.g., lactococcus lactis W19). Probiotics can reduce the occurrence rate of bacterial infections by stabilizing the gastrointestinal barrier and by banishing pathogens. When taking safety of pro-/synbiotic use in immunocompromised and immunosuppressed patients into account, based on available literature, it may be prudent to avoid products containing Saccharomyces sp., because these products were not used in the efficacy studies. The majority of the adverse event reporting reports products containing Saccharomyces sp. [65].

Limitations of this review were that 3 studies (2 LT studies and 1 LR study) were performed by 1 investigator [40,41], Eguchi et al. had a retrospective control group [42], and 2 of the LR studies were prospective non-randomized studies. The combinations and concentrations of the pro-/synbiotic preparations were different, though Lactobacillus sp. was the main component. The results of the meta-analysis have to be interpreted with caution because the duration of perioperative exposure differed between studies, as well as the control groups being inconsistent (placebo vs. no therapy vs. administration of only prebiotics).

\section{Conclusions}

Perioperative pro-/synbiotics have been investigated in various RCTs in liver surgery with different primary study endpoints. Most of the studies focused on postoperative infections that lead to increased morbidity and mortality but also on intestinal integrity, on the microflora, as well as on the development of perioperative liver function and surgical outcomes. Pro-/synbiotics in liver surgery clearly reduce infections. However, current evidence on the effects of prophylactic perioperative administration of pro-/synbiotics in liver surgery is conflicting due to pending standardization of pro-/synbiotic preparations, duration of perioperative exposure, the route of administration as well as standardized study controls (standard care or placebo), making comparison of the trials challenging.

Supplementary Materials: The following are available online at http://www.mdpi.com/2072-6643/12/8/2461/s1, File S1: Search strategies.

Author Contributions: J.K. and P.S. designed and performed the study, wrote the manuscript, and interpreted the data. G.P. analyzed the data. All authors have read and agreed to the published version of the manuscript.

Funding: This research received no external funding.

Conflicts of Interest: The authors declare no conflicts of interest. 


\section{References}

1. Rayes, N.; Schutz, T.; Lochs, H. Probiotika, Prabiotika und Synbiotika in der Chirurgie und bei kritisch Kranken auf der Intensivstation. Leberresektion, Transplantation. In Probiotika, Präbiotika and Synbiotika, 1st ed.; Bischoff, S.C., Ed.; Georg Thieme Verlag KG: Stuttgart, Germany, 2009; p. 296.

2. Rahbari, N.N.; Wente, M.; Schemmer, P.; Diener, M.K.; Hoffmann, K.; Motschall, E.; Schmidt, J.; Weitz, J.; Büchler, M.W. Systematic review and meta-analysis of the effect of portal triad clamping on outcome after hepatic resection. Br. J. Surg. 2008, 95, 424-432. [CrossRef] [PubMed]

3. Rahbari, N.N.; Elbers, H.; Koch, M.; Vogler, P.; Striebel, F.; Bruckner, T.; Mehrabi, A.; Schemmer, P.; Büchler, M.W.; Weitz, J. Randomized clinical trial of stapler versus clamp-crushing transection in elective liver resection. Br. J. Surg. 2014, 101, 200-207. [CrossRef] [PubMed]

4. Hoffmann, K.; Müller-Bütow, V.; Franz, C.; Hinz, U.; Longerich, T.; Büchler, M.W.; Schemmer, P. Factors predictive of survival after stapler hepatectomy of hepatocellular carcinoma: A multivariate, single-center analysis. Anticancer Res. 2014, 34, 767-776. [PubMed]

5. Bruns, H.; Lozanovski, V.J.; Schultze, D.; Hillebrand, N.; Hinz, U.; Büchler, M.W.; Schemmer, P. Prediction of postoperative mortality in liver transplantation in the era of MELD-based liver allocation: A multivariate analysis. PLoS ONE 2014, 9, e98782. [CrossRef]

6. Hoffmann, K.; Unsinn, M.; Hinz, U.; Weiss, K.H.; Waldburger, N.; Longerich, T.; Radeleff, B.; Schirmacher, P.; Büchler, M.W.; Schemmer, P. Outcome after a liver resection of benign lesions. HPB (Oxford) 2015, 17, 994-1000. [CrossRef]

7. Schemmer, P.; Friess, H.; Büchler, M.W. Recent advances in surgical therapy for primary and metastatic liver cancer. Ann. Surg. Hepatol. 2002, 7, 124-133.

8. Nickkholgh, A.; Weitz, J.; Encke, J.; Sauer, P.; Mehrabi, A.; Büchler, M.W.; Schmidt, J.; Schemmer, P. Utilization of extended donor criteria in liver transplantation: A comprehensive review of the literature. Nephrol. Dial. Transplant. 2007, 22, viii29-viii36. [CrossRef]

9. Schemmer, P.; Friess, H.; Dervenis, C.; Schmidt, J.; Weitz, J.; Uhl, W.; Büchler, M.W. The use of endo GIA vascular staplers in liver surgery and their potential benefit: A review. Dig. Surg. 2007, 24, 300-305. [CrossRef]

10. Schemmer, P.; Bruns, H.; Weitz, J.; Schmidt, J.; Büchler, M.W. Liver transection using vascular stapler: A review. HPB (Oxford) 2008, 10, 249-252. [CrossRef]

11. Lin, S.; Hoffmann, K.; Schemmer, P. Treatment of hepatocellular carcinoma: A systematic review. Liver Cancer 2012, 1, 144-158. [CrossRef]

12. Gotthardt, D.N.; Weiss, K.H.; Rupp, C.; Bode, K.; Eckerle, I.; Rudolph, G.; Bergemann, J.; Kloeters-Plachky, P.; Chahoud, F.; Büchler, M.W.; et al. Bacteriobilia and fungibilia are associated with outcome in patients with endoscopic treatment of biliary complications after liver transplantation. Endoscopy 2013, 45, 890-896. [CrossRef] [PubMed]

13. Fishman, J.A. Infection in solid-organ transplant recipients. N. Engl. J. Med. 2007, 357, 2601-2614. [CrossRef] [PubMed]

14. Xourafas, D.; Pawlik, T.M.; Cloyd, J.M. Early Morbidity and Mortality after Minimally Invasive Liver Resection for Hepatocellular Carcinoma: A Propensity-Score Matched Comparison with Open Resection. J. Gastrointest. Surg. 2019, 23, 1435-1442. [CrossRef] [PubMed]

15. Gan, Y.; Su, S.; Li, B.; Fang, C. Efficacy of probiotics and prebiotics in prevention of infectious complications following hepatic resections: Systematic review and meta-analysis. J. Gastrointest. Liver Dis. 2019, 28, 205-211. [CrossRef] [PubMed]

16. Angus, D.C.; Linde-Zwirble, W.T.; Lidicker, J.; Clermont, G.; Carcillo, J.; Pinsky, M.R. Epidemiology of severe sepsis in the United States: Analysis of incidence, outcome, and associated costs of care. Crit. Care Med. 2001, 29, 1303-1310. [CrossRef] [PubMed]

17. Kaido, T.; Mori, A.; Oike, F.; Mizumoto, M.; Ogura, Y.; Hata, K.; Yoshizawa, A.; Iida, T.; Uemoto, S. Impact of pretransplant nutritional sta- tus in patients undergoing liver transplantation. Hepatogastroenterology 2010, 57, 1489-1492.

18. Singh, N.; Paterson, D.L.; Gayowski, T.; Wagener, M.M.; Marino, I.R. Predicting bacteremia and bacteremic mortality in liver transplant recipients. Liver Transplant. 2000, 6, 54-61. [CrossRef] 
19. Martin, G.S.; Mannino, D.M.; Eaton, S.; Moss, M. The epidemiology of sepsis in the United States from through 2000. N. Engl. J. Med. 2003, 348, 1546-1554. [CrossRef]

20. Bateman, B.T.; Schmidt, U.; Berman, M.F.; Bittner, E.A. Temporal trends in the epidemiology of severe postoperative sepsis after elective surgery: A large, nationwide sample. Anesthesiology 2010, 112, 917-925. [CrossRef]

21. Moore, L.J.; Moore, F.A.; Todd, S.R.; Jones, S.L.; Turner, K.L.; Bass, B.L. Sepsis in general surgery: The 2005-National surgical quality improvement program perspective. Arch. Surg. 2010, 145, 695-700. [CrossRef]

22. Vogel, T.R.; Dombrovskiy, V.Y.; Carson, J.L.; Graham, A.M.; Lowry, S.F. Postoperative sepsis in the United States. Ann. Surg. 2010, 252, 1065-1071. [CrossRef] [PubMed]

23. Allen, S.J.; Martinez, E.G.; Gregorio, G.V.; Dans, L.F. Probiotics for treating acute infectious diarrhoea. Cochrane Database Syst. Rev. 2010, 2010, CD003048. [CrossRef] [PubMed]

24. Huang, J.S.; Bousvaros, A.; Lee, J.W.; Diaz, A.; Davidson, E.J. Efficacy of probiotic use in acute diarrhea in children: A meta-analysis. Dig. Dis. Sci. 2002, 47, 2625-2634. [CrossRef] [PubMed]

25. Szajewska, H.; Mrukowicz, J.Z. Probiotics in the treatment and prevention of acute infectious diarrhea in infants and children: A systematic review of published randomized, double-blind, placebo-controlled trials. J. Pediatr. Gastroenterol. Nutr. 2001, 33 (Suppl. S2), 17-25. [CrossRef] [PubMed]

26. Van Niel, C.W.; Feudtner, C.; Garrison, M.M.; Christakis, D.A. Lactobacillus therapy for acute infectious diarrhea in children: A meta-analysis. Pediatrics 2002, 109, 678-684. [CrossRef]

27. McFarland, L.V. Meta-analysis of probiotics for the prevention of traveler's diarrhea. Travel Med. Infect. Dis. 2007, 5, 97-105. [CrossRef]

28. Johnston, B.C.; Supina, A.L.; Ospina, M.; Vohra, S. Probiotics for the prevention of pediatric antibiotic-associated diarrhea. Cochrane Database Syst. Rev. 2007, 2007, CD004827.

29. Johnston, B.C.; Supina, A.L.; Ospina, M.; Vohra, S. Probiotics for pediatric antibiotic-associated diarrhea: A meta-analysis of randomized placebo-controlled trials. CMAJ 2006, 175, 377-383. [CrossRef]

30. Szajewska, H.; Ruszczyński, M.; Radzikowski, A. Probiotics in the prevention of antibiotic-associated diarrhea in children: A meta-analysis of randomized controlled trials. J. Pediatr. 2006, 149, 367-372. [CrossRef]

31. Cremonini, F.; Di Caro, S.; Nista, E.C.; Bartolozzi, F.; Capelli, G.; Gasbarrini, G.; Gasbarrini, A. Meta-analysis: The effect of probiotic administration on antibiotic-associated diarrhoea. Aliment. Pharmacol. Ther. 2002, 16, 1461-1467. [CrossRef]

32. D'Souza, A.L.; Rajkumar, C.; Cooke, J.; Bulpitt, C.J. Probiotics in prevention of antibiotic associated diarrhoea: Meta-analysis. BMJ 2002, 324, 1361. [CrossRef] [PubMed]

33. Hawrelak, J.A.; Whitten, D.L.; Myers, S.P. Is Lactobacillus rhamnosus GG effec- tive in preventing the onset of antibiotic-associated diarrhoea: A systematic review. Digestion 2005, 72, 51-56. [CrossRef] [PubMed]

34. Szajewska, H.; Mrukowicz, J. Meta-analysis: Non-pathogenic yeast Saccharo- myces boulardii in the prevention of antibiotic-associated diarrhoea. Aliment. Pharmacol. Ther. 2005, 22, 365-372. [CrossRef] [PubMed]

35. Ng, S.C.; Hart, A.L.; Kamm, M.A.; Stagg, A.J.; Knight, S.C. Mechanisms of action of probiotics: Recent advances. Inflamm. Bowel Dis. 2009, 15, 300-310. [CrossRef] [PubMed]

36. Shen, T.D.; Pyrsopoulos, N.; Rustgi, V.K. Microbiota and the liver. Liver Transplant. 2018, 24, 539-550. [CrossRef]

37. Higgins, J.P.; Altman, D.G.; Gøtzsche, P.C.; Jüni, P.; Moher, D.; Oxman, A.D.; Savovic, J.; Schulz, K.F.; Weeks, L.; Sterne, J.A. Cochrane Bias Methods Group; Cochrane Statistical Methods Group. The Cochrane Collaboration's tool for assessing risk of bias in dandomised trials. BMJ 2011, 343, d5928. [CrossRef]

38. Wells, G.A.; Shea, B.; O'Connell, D. The Newcastle-Ottawa Scale (NOS) for Assessing the Quality of Non-Randomised Studies in Meta-Analyses. Available online: http:/www.ahri.a/programs/clinical_ epidemiology/oxford.asp (accessed on 27 October 2017).

39. Grąt, M.; Wronka, K.M.; Lewandowski, Z.; Grąt, K.; Krasnodębski, M.; Stypułkowski, J.; Hołówko, W.; Masior, Ł.; Kosińska, I.; Wasilewicz, M.; et al. Effects of continuous use of probiotics before liver transplantation: A randomized, double-blind, placebo- controlled trial. Clin. Nutr. 2017, 36, 1530-1539. [CrossRef]

40. Rayes, N.; Seehofer, D.; Hansen, S.; Boucsein, K.; Müller, A.R.; Serke, S.; Bengmark, S.; Neuhaus, P. Early enteral supply of lactobacillus and fiber versus selective bowel decontamination: A controlled trial in liver transplant recipients. Transplantation 2002, 74, 123-127. [CrossRef] 
41. Rayes, N.; Seehofer, D.; Theruvath, T.; Schiller, R.A.; Langrehr, J.M.; Jonas, S.; Bengmark, S.; Neuhaus, P. Supply of pre- and probiotics reduces bacterial infection rates after liver transplantation-A randomized, double-blind trial. Am. J. Transplant. 2005, 5, 125-130. [CrossRef]

42. Eguchi, S.; Takatsuki, M.; Hidaka, M.; Soyama, A.; Ichikawa, T.; Kanematsu, T. Perioperative synbiotic treatment to prevent infectious complications in patients after elective living donor liver transplantation: A prospective randomized study. Am. J. Surg. 2011, 201, 498-502. [CrossRef]

43. Zhang, Y.; Chen, J.; Wu, J.; Chalson, H.; Merigan, L.; Mitchell, A. Probiotic use in preventing postoperative infection in liver transplant patients. Hepatobiliary Surg. Nutr. 2013, 2, 142-147. [PubMed]

44. Kanazawa, H.; Nagino, M.; Kamiya, S.; Komatsu, S.; Mayumi, T.; Takagi, K.; Asahara, T.; Nomoto, K.; Tanaka, R.; Nimura, Y. Synbiotics reduce postoperative infectious complications: A randomized controlled trial in biliary cancer patients undergoing hepatectomy. Langenbecks Arch. Surg. 2005, 390, 104-113. [CrossRef] [PubMed]

45. Liu, Z.; Li, C.; Huang, M.; Tong, C.; Zhang, X.; Wang, L.; Peng, H.; Lan, P.; Zhang, P.; Huang, N.; et al. Positive regulatory effects of perioperative probiotic treatment on postoperative liver complications after colorectal liver metastases surgery: A double-center and double-blind randomized clinical trial. BMC Gastroenterol. 2015, 15, 34. [CrossRef] [PubMed]

46. Rifatbegovic, Z.; Mesic, D.; Ljuca, F.; Zildzic, M.; Avdagic, M.; Grbic, K.; Agic, M.; Hadziefendic, B. Effect of probiotics on liver function after surgery resection for malignancy in the liver cirrhotic. Med. Arch. 2010, 64, 208-211.

47. Rayes, N.; Pilarski, T.; Stockmann, M.; Bengmark, S.; Neuhaus, P.; Seehofer, D. Effect of pre- and probiotics on liver regeneration after resection: A randomised, double-blind pilot study. Benef. Microbes 2012, 3, 237-244. [CrossRef]

48. Usami, M.; Miyoshi, M.; Kanbara, Y.; Aoyama, M.; Sakaki, H.; Shuno, K.; Hirata, K.; Takahashi, M.; Ueno, K.; Tabata, S.; et al. Effects of perioperative synbiotic treatment on infectious complications, intestinal integrity, and fecal flora and organic acids in hepatic surgery with or without cirrhosis. JPEN J. Parenter. Enter. Nutr. 2011, 35, 317-328. [CrossRef]

49. Sugawara, G.; Nagino, M.; Nishio, H.; Ebata, T.; Takagi, K.; Asahara, T.; Nomoto, K.; Nimura, Y. Perioperative Synbiotic Treatment to Prevent Postoperative Infectious Complications in Biliary Cancer Surgery: A Randomized Controlled Trial. Ann. Surg. 2006, 244, 706-714. [CrossRef]

50. Iida, H.; Sasaki, M.; Maehira, H.; Mori, H.; Yasukawa, D.; Takebayashi, K.; Kurihara, M.; Bamba, S.; Tani, M. The effect of preoperative synbiotic treatment to prevent surgical-site infection in hepatic resection. J. Clin. Biochem. Nutr. 2020, 66, 67-73. [CrossRef]

51. Sawas, T.; Al Halabi, S.; Hernaez, R.; Carey, W.D.; Cho, W.K. Patients Receiving Prebiotics and Probiotics Before Liver Transplantation Develop Fewer Infections Than Controls: A Systematic Review and Meta-Analysis. Clin. Gastroenterol. Hepatol. 2015, 13, 1567-1574. [CrossRef]

52. Chow, J.C.; Young, D.W.; Golenbock, D.T.; Christ, W.J.; Gusovsky, F. Toll-like receptor-mediates lipopolysaccharide-induced signal transduction. J. Biol. Chem. 1999, 274, 10689-10692. [CrossRef]

53. Faure, E.; Equils, O.; Sieling, P.A.; Thomas, L.; Zhang, F.X.; Kirschning, C.J.; Polentarutti, N.; Muzio, M.; Arditi, M. Bacterial lipopolysaccharide activates NF-kappaB through toll-like receptor (TLR-4) in cultured human dermal endothelial cells. Differential expression of TLR-and TLR-in endothelial cells. J. Biol. Chem. 2000, 275, 11058-11063. [CrossRef] [PubMed]

54. Rousseaux, C.; Thuru, X.; Gelot, A.; Barnich, N.; Neut, C.; Dubuqoy, L.; Dubuquoy, C.; Merour, E.; Geboes, K.; Chamaillard, M.; et al. Lactobacillus acidophilus modulates intestinal pain and induces opioid and cannabinoid receptors. Nat. Med. 2007, 13, 35-37. [CrossRef] [PubMed]

55. Finnerty, C.C.; Mabvuure, N.T.; Ali, A.; Kozar, R.A.; Herndon, D.N. The surgically induced stress response. JPEN J. Parenter. Enter. Nutr. 2013, 37 (Suppl. S5), 21S-29S. [CrossRef] [PubMed]

56. Chowdhury, A.H.; Adiamah, A.; Kushairi, A.; Varadhan, K.K.; Krznaric, Z.; Kulkarni, A.D.; Neal, K.R.; Lobo, D.N. Perioperative Probiotics or Synbiotics in Adults Undergoing Elective Abdominal Surgery: A Systematic Review and Meta-analysis of Randomized Controlled Trials. Ann. Surg. 2020, 271, 1036-1047. [CrossRef] 
57. Skonieczna-Żydecka, K.; Kaczmarczyk, M.; Łoniewski, I.; Lara, L.F.; Koulaouzidis, A.; Misera, A.; Maciejewska, D.; Marlicz, W. A Systematic Review, Meta-Analysis, and Meta-Regression Evaluating the Efficacy and Mechanisms of Action of Probiotics and Synbiotics in the Prevention of Surgical Site Infections and Surgery-Related Complications. J. Clin. Med. 2018, 7, 556. [CrossRef]

58. Moran, C.P.; Musa, S.A.; Rahman, T.M. The use of probiotics in the surgical patient. Eur. Surg. 2011, 44, 91-98. [CrossRef]

59. Masuda, T.; Shirabe, K.; Yoshiya, S.; Matono, R.; Morita, K.; Hashimoto, N.; Ikegami, T.; Yoshizumi, T.; Baba, H.; Maehara, Y. Nutrition Support and Infections Associated With Hepatic Resection and Liver Transplantation in Patients With Chronic Liver Disease. J. Parenter. Enter. Nutr. 2012, 37, 318-326. [CrossRef]

60. Schnabl, B.; Brenner, D.A. Interactions between the intestinal microbiome and liver diseases. Gastroenterology 2014, 146, 1513-1524. [CrossRef]

61. Liu, Q.; Duan, Z.P.; Ha, D.K.; Bengmark, S.; Kurtovic, J.; Riordan, S.M. Synbiotic modulation of gut flora: Effect on minimal hepatic encephalopathy in patients with cirrhosis. Hepatology 2004, 39, 1441-1449. [CrossRef]

62. Horvath, A.; Leber, B.; Schmerboeck, B.; Tawdrous, M.; Zettel, G.; Hartl, A.; Madl, T.; Stryeck, S.; Fuchs, D.; Lemesch, S.; et al. Randomised clinical trial: The effects of a multispecies probiotic vs. placebo on innate immune function, bacterial translocation and gut permeability in patients with cirrhosis. Aliment. Pharmacol. Ther. 2016, 44, 926-935. [CrossRef]

63. Yeh, D.C.; Wu, C.C.; Ho, W.M.; Cheng, S.B.; Lu, I.Y.; Liu, T.J.; P'eng, F.K. Bacterial translocation after cirrhotic liver resection: A clinical investigation of patients. J. Surg. Res. 2003, 111, 209-214. [CrossRef]

64. Viehman, J.A.; Clancy, C.J.; Clarke, L.; Shields, R.K.; Silveira, F.P.; Kwak, E.J.; Vergidis, P.; Hughes, C.; Humar, A.; Nguyen, M.H. Surgical site infections after liver transplantation: Emergence of multidrug-resistant bacteria and implications for prophylaxis and treatment strategies. Transplantation 2016, 100, 2107-2114. [CrossRef] [PubMed]

65. Jorgenson, M.R.; Descourouez, J.L.; Siodlak, M.; Tjugum, S.; Rice, J.P.; Fernandez, L.A. Efficacy and Safety of Probiotics and Synbiotics in Liver Transplantation. Pharmacotherapy 2018, 38, 758-768. [CrossRef] [PubMed]

(C) 2020 by the authors. Licensee MDPI, Basel, Switzerland. This article is an open access article distributed under the terms and conditions of the Creative Commons Attribution (CC BY) license (http://creativecommons.org/licenses/by/4.0/). 